7 Loh EY, Elliott JF, Cwirla S, Lanier LL, Davis MM. Polymerase chain reaction with single-sided specificity: analysis of $T$ cell receptor delta chain. Science 1989;243:217-20.

8 Weber JL, May PE. Abundant class of human DNA polymorphisms which can be typed using the polymerase chain reaction. Am $f$ Hum Genet 1989;44:388-96.

9 Richards RI, Sutherland GR. Dynamic mutations: a new class of mutations causing human disease. Cell 1992;70:709-12.

10 Gyllesten UB, Erlich HA. Generation of single-stranded DNA by the polymerase chain reaction and its application to direct sequencing of the polymerase chain reaction and its application to direct

11 Sarkar G, Sommer SS. Shedding light on PCR contamination. Nature 1990;343:27.

12 Tindall KR, Kunkel TA. Fidelity of DNA synthesis by the Thermus aquaticus DNA polymerase. Biochemistry 1988;27:6008-13.

13 Chelly J, Kaplan JC, Maire P, Gautron S, Kahn A. Transcription of the dystrophin gene in human muscle and non-muscle tissue. Nature 1988; 333:858.

14 Nelson DL, Ledbetter SA, Corbo L, Victoria MF, Ramirez-Solis R, Webster $\mathrm{TD}$, et al. Alu polymerase chain reaction: a method for rapid isolation of human-specific sequences from complex DNA sources. Proc Natl Acad Sci USA 1989;86:6686-9.

15 Triglia T, Peterson MG, Kemp DJ. A procedure for in vitro amplification of DNA segments that lie outside the boundaries of known sequences. Nucleic Acids Research 1988;16:8186.

16 Ochman H, Gerber AS, Hart DL. Genetic applications of an inverse polymerase chain reaction. Genetics 1988;120:621-3.

17 Riley JH, Butler R, Ogilvie D, Finniear R, Jenner DE, Powell S, et al. A novel, rapid method for the isolation of terminal sequences from yeast artificial rapid method for the isolation of terminal sequences from yeast

18 Handyside AH, Pattinson JK, Penketh RJA, Delhanty JDA, Winston RMI Tuddenham EGD. Biopsy of human preimplantation embryos and sexing by DNA amplification. Lancet 1989;i:347-9.
19 Newton CR, Graham A, Heptinstall LE, Powell SJ, Summers C, Kalsheker N, et al. Analysis of any point mutation in DNA. The amplification refractory mutation system (ARMS). Nucleic Acids Research 1989;17:2503-16.

20 Ferrie RM, Schwarz MJ, Robertson NH, Vaudin S, Super M, Malone G, et al. Development, multiplexing and application of ARMS tests for common mutations in the CFTR gene. Am $\mathcal{F}$ Hum Genet 1992;51:251-62.

21 Todd JA, Bell JI, McDevitt HO. HLA-DQ beta gene contributes to susceptibility and resistance to insulin-dependent diabetes mellitus. Nature 1987; 329:599-604.

22 Cambien F, Poirier O, Lecerf L, Evans A, Cambou JP, Arveiler D, et al. Deletion polymorphism in the gene for angiotensin-converting enzyme is a potent risk factor for myocardial infarction. Nature 1992;359:641-4

23 Jeunemaitre X, Soubrier F, Kotelevtsev YV, Lifton RP, Williams CS, Charr $A$, et al. Molecular basis of human hypertension: role of angiotensinogen. Cell 1992;71:169-80.

24 Lo Y-MD, Patel P, Wainscoat JS, Sampietro M, Gillmer MD, Fleming KA Prenatal sex determination by DNA amplification from maternal peripheral blood. Lancet 1989;ii:1363-5.

25 Sidransky D, Von Eschenbach A, Tsai YC, Jones P, Summerhays I, Marshal $\mathrm{F}$, et al. Identification of $\mathrm{p} 53$ gene mutations in bladder cancers and urine samples. Science 1991;252:706-9.

26 Powell SM, Zilz N, Beazer-Barclay Y, Bryan TM, Hamilton SR, Thibodea $\mathrm{SN}$, et al. APC mutations occur early during colorectal tumorigenesis. Nature 1992;359:235-7.

27 Sidransky D, Tokino T, Hamilton SR, Kinzler K, Levin B. Frost P, et al. Identification of ras oncogene mutations in the stool of patients with curable colorectal tumors. Science 1992;256:102-5.

28 Smith B, Selby P, Southgate J, Pittman K, Bradley C, Blair GE. Detection of melanoma cells in peripheral blood by means of reverse transcriptase and polymerase chain reaction. Lancet 1991 ;ii:1227-9.

29 Fountain JW, Graw SL, Kao W, Stanton VP, Aburatani H, Munroe DJ, et al. Further characterisation of the $9 \mathrm{p} 21$ region frequently deleted in human cutaneous melanoma. Am $\mathcal{J}$ Hum Genet 1992;51:A51.

\title{
Letter from Albania
}

\section{A country in transition}

Hans Veeken

"That will get stolen," the minister of health exclaims when I show him the picture of the pressure cooker that is meant to be used as a steriliser in the dispensaries. He immediately realises the impact of his remark and adds reassuringly: "We will take measures to prevent that, of course."

Working as a medical coordinator for Médecins Sans Frontières I had the privilege to work in Albania during the period of transition since communism has been discarded. I arrived at Christmas 1991. There was snow and frost, and the minister received me in his fur coat because there was no heating. During the following months we started to distribute basic medical material to dispensaries, health centres, and hospitals in a few districts. I travelled extensively throughout the country for six months to prepare for a nationwide extension of the programme, which was funded by the European Community.

\section{Basics to start with}

The director of the district hospital in Corovoda shows me his hospital with enthusiasm. "Have a cigarette," he says, and as if to persuade me he lights one himself in the corridor. The ash will be scattered on the floor throughout the hospital. "Can't you provide us with a new $x$ ray machine, incubators, analysers, and an ultrasound machine? These are things that every hospital needs, don't you agree?" The director is visibly disappointed when I explain that we will start with the basics and that we will not spend the whole budget on a new $x$ ray machine.

The building is decrepit, the doors do not shut, the windows have no glass, some taps leak continuously, the staff are too embarrassed to show me the lavatories. The guided tour takes the form of a procession; all doctors are interested to speak to a foreigner. Despite their isolation the doctors often speak foreign languages. During the visit I do not get the impression that I'm keeping any of them from their work. The reason is simple: there are hardly any patients. "Are the Albanians that healthy?" I ask innocently. He grabs me amicably by the shoulder, pinches me firmly, and explains that since the Chinese left no new equipment has been purchased. The patients realise this and they do not expect any effective help anymore: medicines, sutures, needles are all-scarce or absent. Furthermore, it is so cold during this time of the year that, without heating, patients do not want to be admitted.

The way that doctors and other staff associate with each other is much less formal than we are used to in Western countries. The level of their salaries is equally striking: doctors earn $\$ 14$ a month and nurses $\$ 10$. At an average expenditure of $\$ 17$ per head, the budget of the Ministry of Health is scarcely sufficient to pay the salaries, let alone to purchase any new equipment. The scarcity is beyond words; even the most basic materials such as gauzes, needles, and syringes cannot be found. The hardware, such as $x$ ray, theatre, and laboratory equipment, is still of Chinese or even Russian origin, with some items being over 40 years old. Autoclaves are functioning but neither the pressure gauge, thermometer, nor the timer are working. The sterilising procedure is guided by intuition alone, the high prevalence of hepatitis B proves that this is not the best method. In the corridor I'm addressed by another doctor. "Do we get a sphygmomanometer? How can we work seriously without one?" A sphygmomanometer, a thermometer, scales-all are rarities in the hospital. The surgeon presses his stethoscope in my hands: "What is your opinion of this patient?" he asks. The stethoscope keeps silent. I adjust the earplugs, with no result. Helplessly I look up from the patient. The doctors laugh and the surgeon says: "Yes we do know how to examine our patients, even without proper equipment," as if to convince me of their capabilities. I examine the stethoscope instead of the patient and notice that the membrane is missing.

The statistics suggest that people's health is not too
Admiraal de Ruyterweg 134,

Netherlands

BMF 1993;306:446-7 


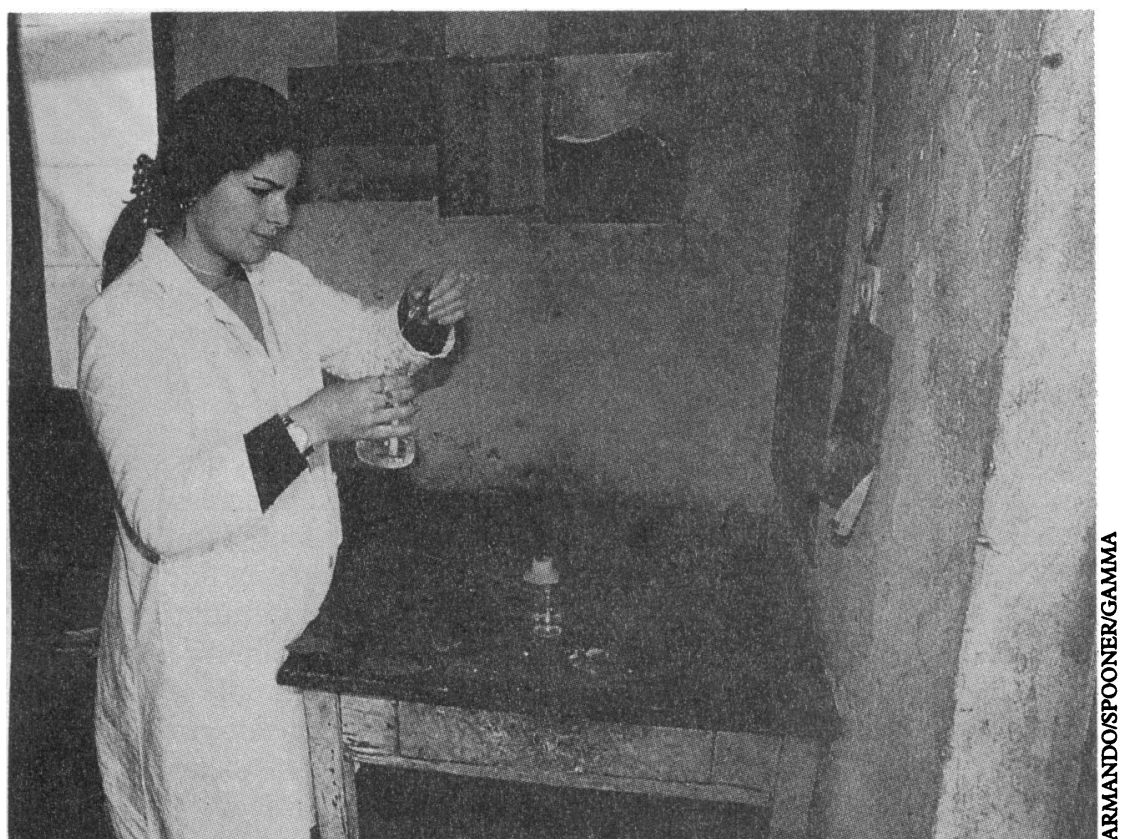

A maternity unit in Tirane from the district capital is no exception. The road follows the river. We cross it, again and again. To my astonishment $I$ find that we use the river bed as a road. When we reach the village we cannot find the dispensary. A small boy guides us to a heap of stones. "That is the clinic, doctor. Half a year ago it was destroyed. Shall I take you to the nurse?" he asks me. It turns out that nearly all dispensaries are either destroyed, looted, or too decrepit to work in.

The transition period in Albania started with anarchy when people vented their rage on government buildings such as schools and dispensaries. We find the village nurse in her house. "Yes, of course I still work, I vaccinate the children, I visit the people in their homes if necessary, and give injections." The vaccinations are administered regularly. Rituals are still being observed with vaccines being transported in a thermos (yet sometimes without ice) and stored in the neighbour's fridge. On the day of vaccination the vaccines are kept in the table drawer. "What kind of injections are given?" I ask the nurse. "Vitamins, of course, for malaise and antibiotics when the people cough." Inspection of the cupboard shows that these are the main categories; vitamins are available for every letter of the alphabet.

Sterilisation methods are rudimentary. The needles bad. Life expectancy at 72 years is the same as in countries where incomes are three times higher. Without doubt a combination of lifestyle (walking and diet), a high level of education for women, and the wide access to primary health care have contributed to this favourable figure. The reported infant mortality is 30 per 1000 , and a further analysis shows that the mortality in the first week of life is unexpectedly low. I am suspicious. The tendency to achieve planned targets by whatever means is well known in other Eastern block countries.

The staff are unfamiliar with some of the donated materials. We found one part of the delivery bed in the labour ward but the other part turned up in the children's ward. The gynaecologist asks me: "Is this size of vaginal speculum really used in the Netherlands and are the delivery beds that wide?" It needs a practical demonstration and the gynaecologist ends up with his legs in the stirrups. When I told them that I was born in a similar bed and had become a doctor afterwards they were more convinced.

The doctors are proud. "This is not Africa," is an exclamation often heard. Albania, however, definitely is a part of the developing world in the middle of Europe and it is difficult not to compare Albania with my previous experiences in Africa. One big difference is that there are no missionary organisations involved in health care. Once a country that forbade religion by constitution, Albania is now being flooded by all kinds of organisations that try to convert people. The diversity in names is surprising: Save the Savable, Feed the Hungry, God Loves Albania, Foundation for the Freedom of Consciousness.

\section{Schools and clinics destroyed}

We used the opportunity of the trip to visit some remote dispensaries on the way to the district hospital. The scenery throughout the rugged mountain areas is dramatic. A trip of three hours to reach a dispensary are correctly boiled in water but if the water has evaporated fresh water is added and after completion of the procedure the whole pot is transported to the patient's house.

\section{Advantages of isolation}

It will take years for Albania to catch up with the standards of medicine in other European countries but not all the news is negative. Albania does not have to start from scratch. There are many staff with good basic training and the widespread system of primary health care forms an excellent base. This part of the communist system has to be maintained. Replenishment of basic medical materials has priority and should go hand in hand with teaching and retraining staff. Community medicine, family planning, health education need emphasis. The destroyed dispensaries need rebuilding to provide the workers with a reasonable working place. Given the budget restraints of the government, community involvement is essential.

In some ways Albania's isolation has advantages. It would be naive to think that HIV has not crossed the border yet, but compared with other countries Albania is in a favourable position to keep the pandemic within limits. The abuse of intravenous drugs is still uncommon.

Introduction of a free market system seems inevitable. Designing a proper health financing system will be a major challenge and the most important decision for guaranteeing health care for the entire population. With the arrival of the democratic government many Albanians think that it will rain dollars. The new government, with a cardiologist as a president and an anaesthetist as a minister of health, will raise the confidence of many people that the resuscitation of the health system is in good hands. The transition, however, will take years, and a public health approach is essential. 